Balás B. Dénes*

\title{
Nehézpontonhíd építése 1961-ben
}

A második világháborútól a fényképek készültéig eltelt másfél évtizedben többször is megújult az a technika, amelyet a Magyar Honvédség/Magyar Néphadsereg használt pontonhidak építésére. Úgy tudjuk, hogy a honvédség részére az Uhri-féle gyár még a háború alatt gyártott pontonokat, de a háború utáni visszaemlékezők még nyitott dereglyékről is beszéltek, amelyeket rohamcsónakok (rocsók) vontattak fel a hídvonalba.

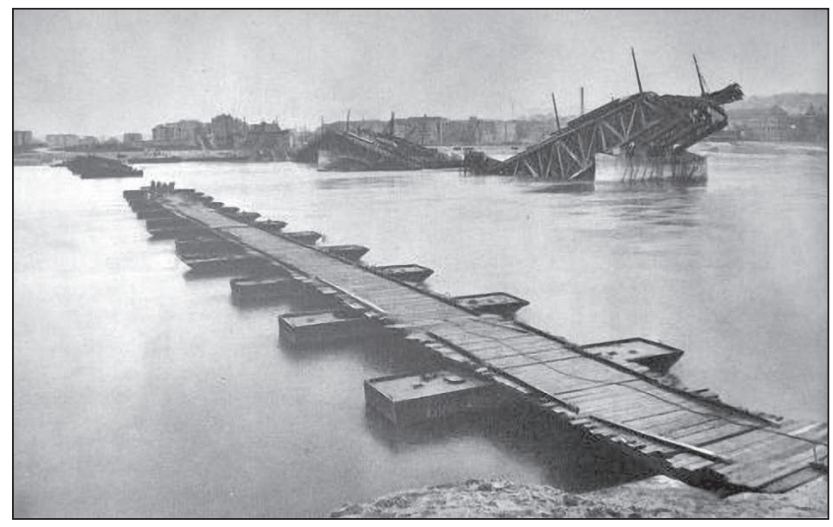

1. ábra. A „Manci híd” építése 1945 tavaszán, valószínúleg szovjet hídanyaggal

Az 1950-es évek erőteljes hadseregfejlesztése ezt a technikát kicserélte: az Ercsiben telepített nehézpontonos hidász alakulatnál az '50-es évek végén, Csepel $B(K) 300$ típusú, összkerékhajtású teherautók szállították a pontonokat, amelyek teljesen zártak lettek.

A rocsók helyett nagy teljesítményű AVM (alumínium vontató motorcsónak) hajók jelentek meg. Ezeket az AVM-eket két Csepel dízelmotor hajtotta, két hajócsavarral. A tiszteletre méltó teljesítmény lehetővé tette, hogy egyszerre 12-18 pontonból áló hídtagot toljanak fel a készülő hídhoz. Az AVM-ek szállítása speciális hajószállító kocsikon történt, azokat eleinte Csepel gyártású, dízelmotoros lánctalpas tüzérségi vontatók, később ZIL teherautók vontatták. A Csepel lánctalpasok (Cs 800-as) motorja ugyanaz a motortípus volt, amelyeket az AVM-ben is használtak.

Ez a technika létezett 1960-ig, amikor megkezdték a járművek lecserélését.

ÖSSZEFOGLALÁS: A magyarországi észak-déli fekvésű Duna-szakasz közepén, Ercsiben települt nehézpontonos hídász zászlóalj 1961-62. évi hídépítéseiből adunk vázlatos beszámolót, elsősorban az 1961 tavaszi hídépítési gyakorlatról, bemutatva az akkor használatos és rendelkezésre álló technikát.

KULCSSZAVAK: Pontonhíd, hídanyag, komp, AVM, Vízőrség, rocsó, ZIL teherautó, hídépítés.

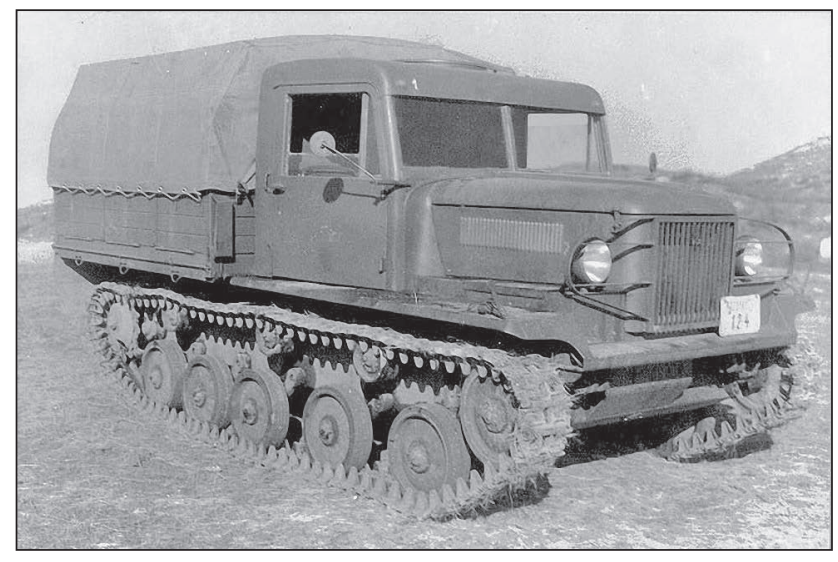

2. ábra. A Cs 800 -as lánctalpas tüzérségi vontató

A mindössze négyesztendős járműpark cseréjének előzménye az alegységeknél legendaként maradt fenn: a Csepel 300-as kocsikat 1956 elején kapta az alakulat, majd még a bejáratási idő alatt (vagy bejáratás nélkül), Győrbe vezényelték a kocsikat az 1956. évi dunai jeges árvíz mentési munkáihoz. Amikor Győrött elmúlt a közvetlen veszély, az alakulatot átirányították Mohácsra, az ottani mentés hasonló feladataihoz.

\section{3. ábra. Pontonnal málházott ZIL-157-es. Jól látszik a} felhúzást végző, pontont rögzítő drótkötél

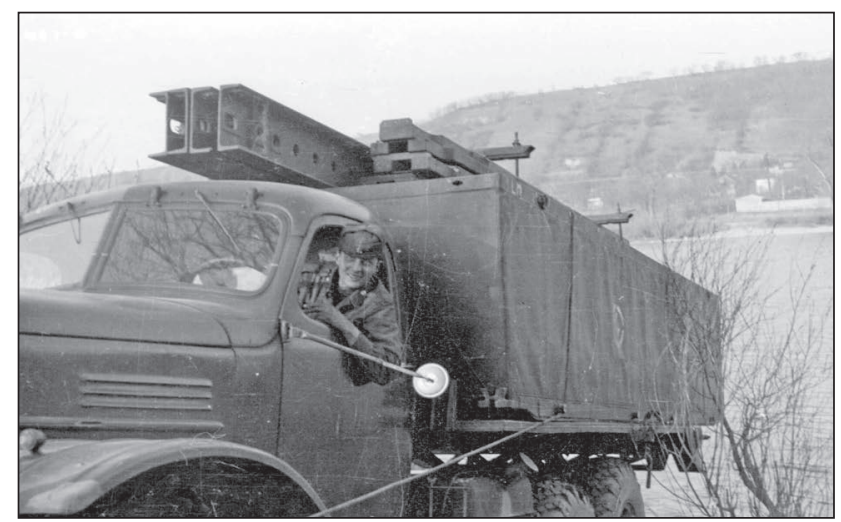

ABSTRACT: This article gives a brief account of the 1961-62 bridge-building activities of the heavy pontoon bridge battalion based in the middle of the Hungarian North-South Danube section, at the town Ercsi; first of all about the spring bridge-building exercise in 1961, providing information about technics used and available at that time.

KEY WORDS: pontoon bridge, bridge construction material, ferry, AVM, Water Guard, assault boat, ZIL truck, bridge-building

\footnotetext{
ORCID: 0000-0001-6573-3764
} 


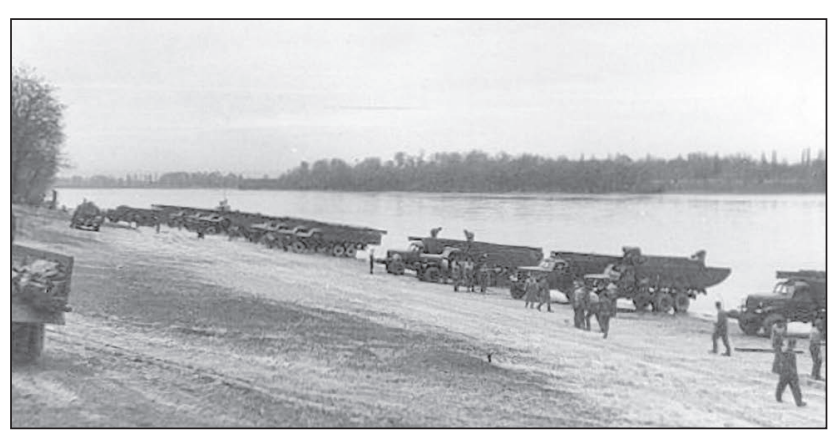

4. ábra. Felsorakozott ZIL-ek kompépítés előtt a Duna Alsógöddel szemközti oldalán, 1961. március 14-én

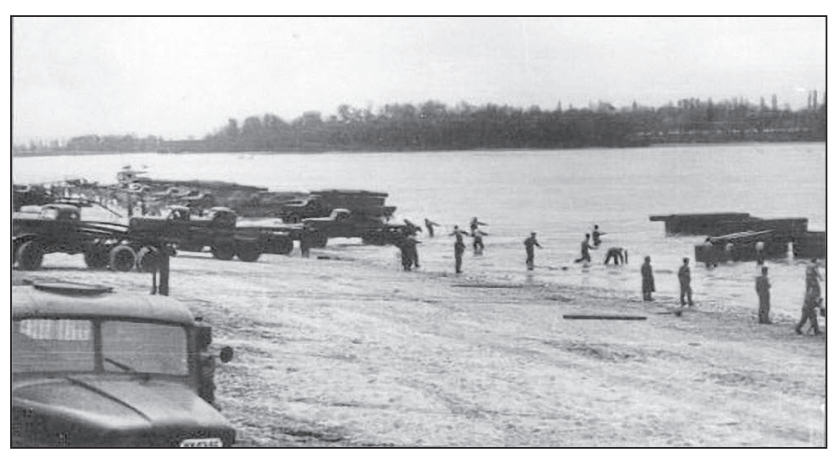

5. ábra. Az első pontonok vízre tétele

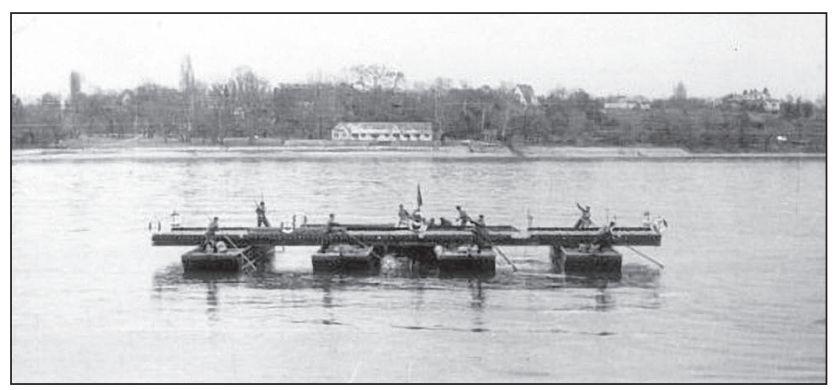

6. ábra. Egy elkészült komp

A menet és a terhelés megpecsételte a bejáratás nélküli Csepelek sorsát, később minden menet a kocsik nagy részének meghibásodásával járt, a jármútechnika megbízhatatlanná vált.

Az új szovjet ZIL-157 típusú pontonszállító járművek több szempontból is újdonságot jelentettek. A hat kerék mindegyike hajtott volt, guminyomásukat a vezetőfülkéből lehetett szabályozni. Ez különösen a felázott talajú folyópartokon jelentett könynyebbséget a gépkocsivezetőknek, csakúgy, mint a csörlőrendszerük, amely lehetővé tette, hogy tíz-tizenkét katona fáradságos munkája helyett, két katona irányításával a kocsi önrakodó módon felcsörlőzze a pontont.

Az új technika kipróbálására és az első gyakorlatra 1961 februárjában került sor az Alsógöddel szemközti Duna-parton. Először a kompépítést gyakorolták, hídépítésre még nem került sor. A kocsikat felsorakoztatták a Duna-parton, oly módon, hogy a hasáb alakú pontonok mellett, minden

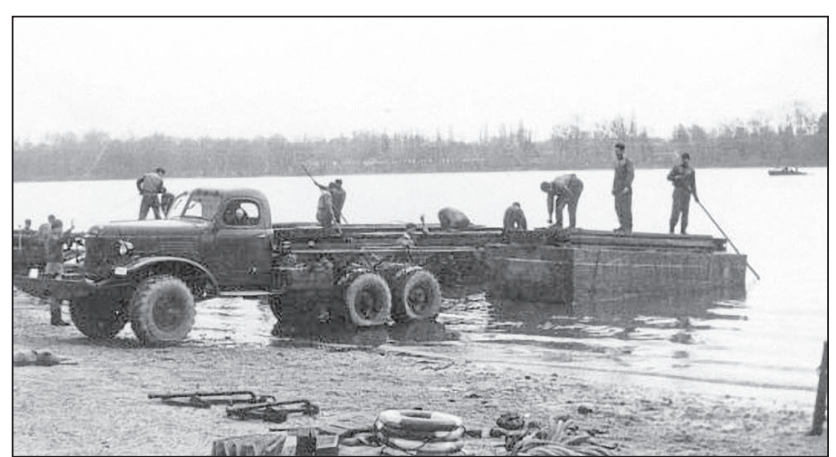

7. ábra. Előkészület a málházáshoz 1.

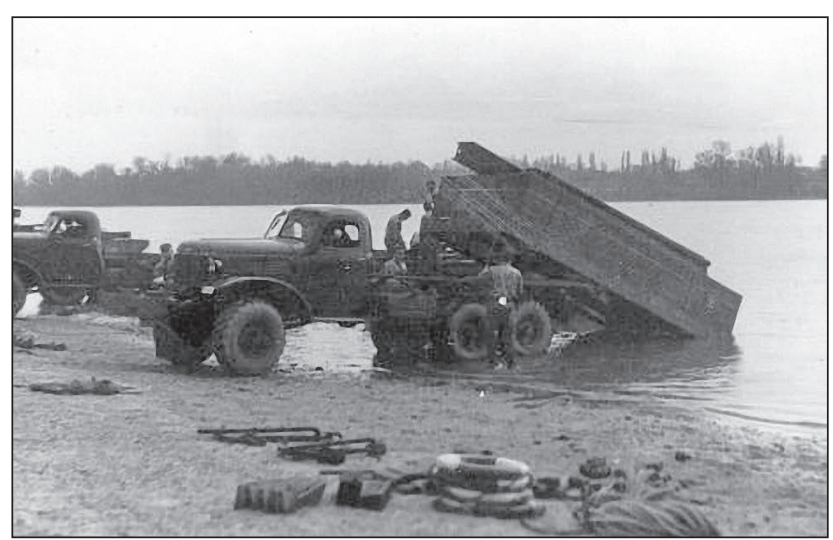

8. ábra. Málházás a ZIL-re 2.

harmadik kocsira ívelt orrú ponton került. Ezeken a pontonorrokon helyezték el a horgonyokat, ezek fordultak szembe a vízfolyással.

A pontonok vízre bocsátása úgy történt, hogy a kocsik farral közelítettek a vízhez, pár métert a vízben haladva hirtelen fékeztek és a ponton a tehetetlenségénél fogva a vízbe zuhant. Az előkészített köteleknél fogva három-négy katona tartotta a pontont, hogy az ne távolodjon meszszebbre. A pontonokat ezután egymáshoz kapcsolták, általában háromból készítettek egy hajót, amelyek elvileg

9. ábra. Zászlóaljtörzs a hídfőben 1961. március 17-én. Balról: két sorállományú technikus, Gilice őrnagy zászlóaljparancsnok, a távcsőnél Szilák százados hadmúveleti tiszt, mögötte Kozma százados vegyivédelmi tiszt

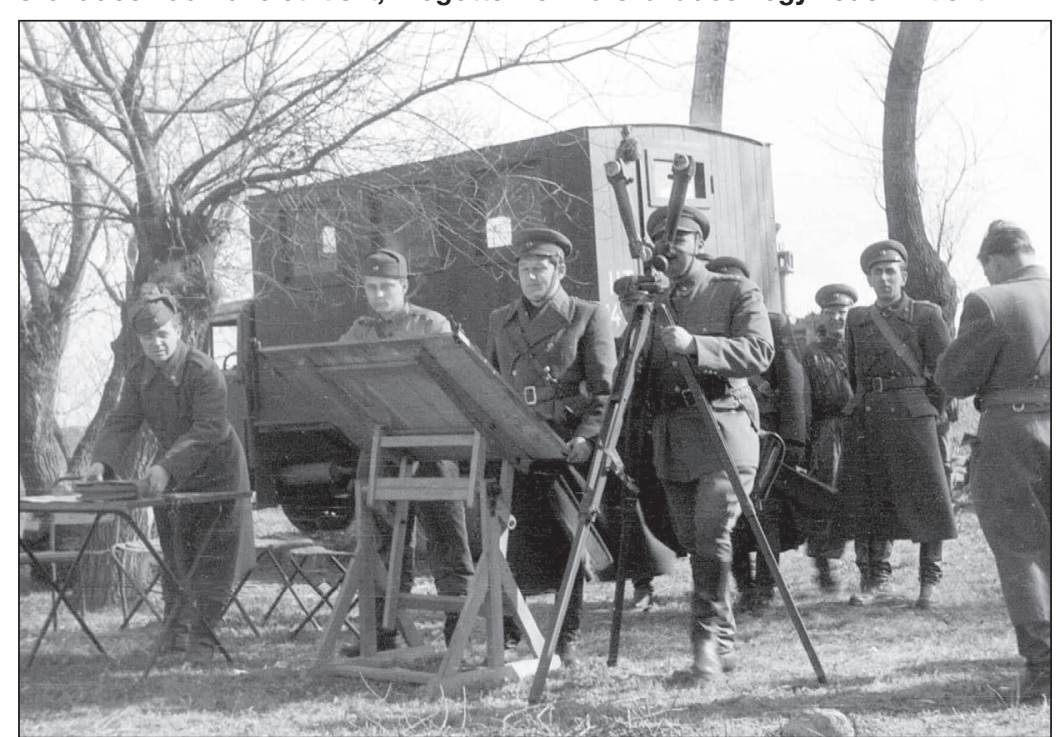




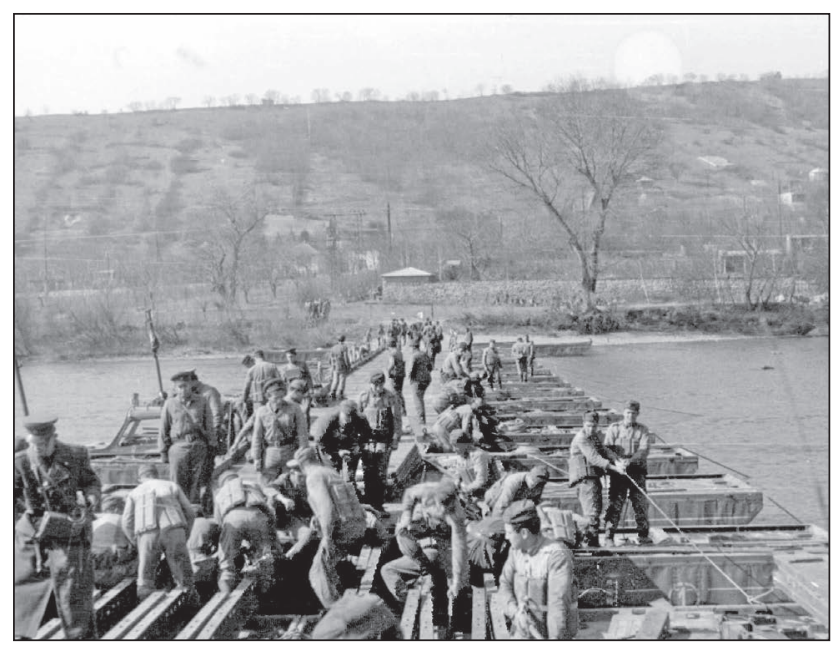

10. ábra. A zárás a legnehezebb és legveszélyesebb múvelet volt

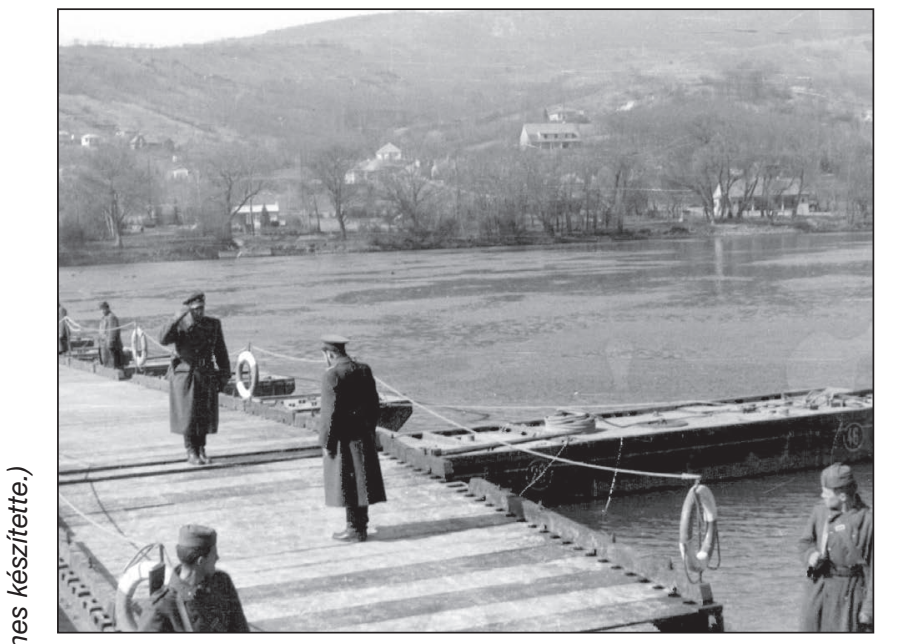

11. ábra. A kész hidat a hadmúveleti tiszt adja át a zászlóaljparancsnoknak (Szilák százados - Gilice őrnagy)

50 tonnát voltak képesek hordozni. A parti feljárók (hídfők) viszont a nagy terhelés miatt öt darab pontont tartalmaztak. Az egymás mellé vontatott ponton-hajókat ún. hossztartók, acélgerendák kötötték össze. Hat hajóból épült fel egy hídtag, négy hajóból egy komp. Egy-egy komp alkalmas volt arra, hogy a folyón átszállítson egy megterhelt teherautót, vagy akár egy harckocsit is.

A gyakorlat a Szentendrei Duna-ágban, Leányfalu alatt, egy kisebb pontonhíd megépítésével folytatódott. A híd építését felderítés, mérések és tervezés előzte meg, a törzsbusz végig a hídfőben tartózkodott, vezényelte az egyes hídtagok elhelyezését és szükség esetén korrigálta a zárótag méretét.

A hídtagokat a Szentendrei-szigeten állították össze, majd az építést a két szemközti partról egyszerre kezdték meg. Ennek az építési módszernek legnehezebb része a középső, ún. „zárótag” beillesztése volt.

A hídépítést megelőzően fontos feladat volt a folyami hajóforgalom zárása. Ezt a feladatot két rohamcsónak (rocsó) látta el, az egyik - a híd felett két kilométerre - az ún. felső vízőrség, a másik a hídvonal alatt, hasonló távolságban. Ezek az őrségek mindaddig léteztek, amíg a híd elzárta a hajózó utat.

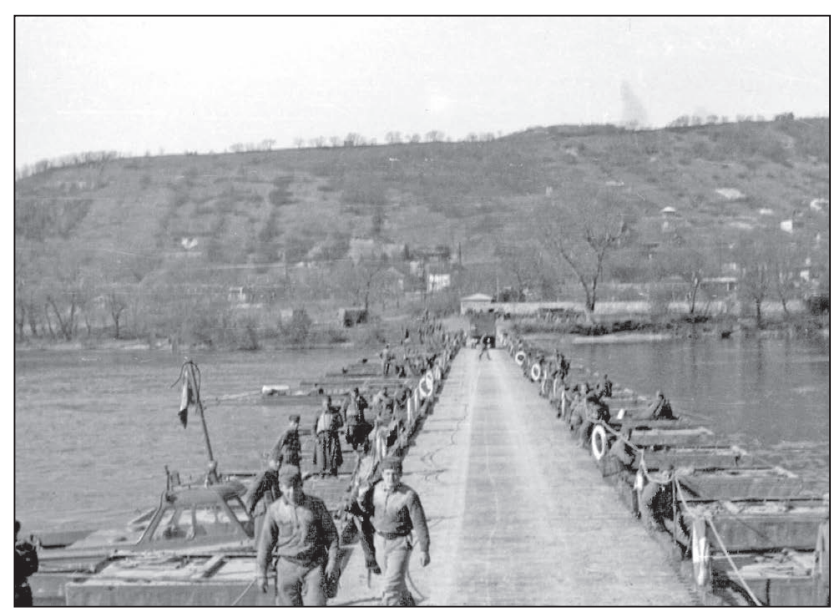

12. ábra. Az elkészült híd Leányfalu alatt a Szentendrei Duna-ágban, 1961. március 17-én. Bal oldalon az AVM-ek készenlétben állnak, szükség esetén "támasztják" a hidat

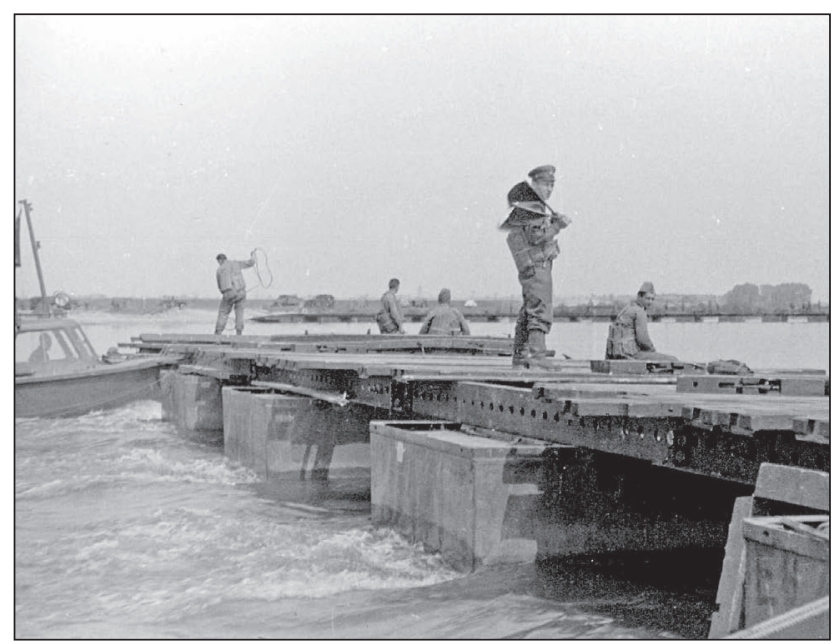

13. ábra. 1961. szeptember 13. A 16 tonnás hídtag toló-úsztatása a hídvonalba. Az úsztatást két AVM végzi

A gyakorlat zárásaként a teljes alakulat átvonult a hídon, majd az elbontott hídanyagot Leányfalunál felmálházták.

Az előkészítő gyakorlatok után 1961 nyarán, az alakulat komoly feladatokat is kapott, például zuhatagi szakaszon kellett hidat építeniük (Visegrádnál). A tatai páncélosok egy jelentős egysége vonult át a bal partról a hídon, Esztergom felé. Más alkalommal Bajánál 1000 méter hosszú híd készült, amelyen egy békéscsabai gépkocsizó lövészezred kelt át.

A hosszú híd építésénél azonban anyaghiány késleltette a híd elkészültét. A Bajánál épített hídhoz olyan mennyiségű pontonra volt szükség, hogy a teherautók egy részét vissza kellett küldeni Ercsibe, tartalék pontonokért.

A hadmúveleti törzs begyakoroltatta a 16 tonna teherbírású hidak építését is. Ezeket általában két óra alatt megépítették, és a szerkezetek alkalmasak voltak arra, hogy gépkocsizó alakulatok - páncélosok nélkül - átkeljenek rajtuk. A 16 tonna teherbírású híd olyan hajókból épült, amelyeket három helyett csak két pontonból álítottak össze. Ennek a hídnak két előnye is volt: kevesebb anyagból, és gyorsabban elkészült.

Ez a technika állt rendelkezésre 1961-62-ben, és alkalmas volt arra, hogy az alakulat szükség esetén a Duna bármely szakaszán 50 tonna teherbírású hidat építsen. 